\title{
Influence of Natural Fluctuations in Seagrass Cover on Commercial Prawn Nursery Grounds in a Subtropical Estuary
}

\author{
Ian A. Halliday \\ Southern Fisheries Centre, Queenskand Department of Primary Industries, PO Box 76, \\ Deception Bay, Qld 4508, Australia.
}

\begin{abstract}
Juvenile prawns were captured with a beam trawl from two intertidal seagrass sites (one sparsely and one densely vegetated) in Tin Can Bay, a subtropical estuary in south-eastern Queensland. The abundance and recruitment patterns of two commercial prawn species (Penaeus plebejus and Metapenaeus bennettae) were investigated. $P$. plebejus was the dominant species at both the sparse and dense seagrass sites. Die-back of the above-ground vegetation in the sparsely vegetated site coincided with a significant increase in the abundance of both $P$. plebejus and $M$. bennettae at this site. Natural loss of intertidal vegetation may cause an immediate reduction in the total fisheries value of an area because of fewer herbivorous commercial fish entering the area. In the longer term, this reduction in the fisheries value of the area may be compensated by an increase in value as a nursery ground for juvenile $P$. plebejus, thereby providing the potential for higher adult $P$. plebejus recruitment to local commercial fisheries and maintaining the overall value of the area.
\end{abstract}

\section{Introduction}

Most commercial prawn species caught in subtropical and tropical Australian waters are dependent on shallow inshore or estuarine environments during some stage of their life cycle (Young 1978; Coles and Lee Long 1985; Staples et al. 1985; Coles et al. 1993). In southern Queensland, about $85 \%$ of the total prawn catch is Penaeus plebejus, except in Moreton Bay where Metapenaeus bennettae and P. esculentus together account for about 50\% (Trainor 1990). $P$. plebejus spawns in offshore oceanic waters and uses estuaries as nursery grounds during the benthic post-larval and juvenile development, whereas $M$. bennettae completes the entire life cycle within estuaries (Dall et al. 1990).

Post-larvae of $P$. plebejus enter estuaries in flood tide currents and settle onto the substratum to prevent the ebb tide carrying them back out (Hughes 1969, 1972; Young and Carpenter 1977). This places post-larval prawns within the estuarine environment but not necessarily on their preferred nursery areas. Juvenile prawns may spend up to a year in the estuary, depending on water temperature, salinity and food abundance (Racek 1959). Nursery areas must provide suitable food and water temperature for growth as well as shelter from predation. Prawn nurseries typically extend from the high water mark to 1 or $2 \mathrm{~m}$ below low water (Penn 1981), with juvenile prawns feeding in the intertidal and subtidal zones during the tidal cycle. Estuaries with high nutrient inputs and large expanses of shallow water provide productive nursery areas for commercial prawn species (Staples 1984; Poiner et al. 1992).
In subtropical Australia, juveniles of $P$. plebejus and $M$. bennettae are found in a range of littoral and sublittoral $(<2 \mathrm{~m})$ habitats. $P$, plebejus is abundant in seagrass and on bare areas with high salinity; however, it is more abundant on seagrass than on bare substratum when both habitats are available (Young 1975). M. bennettae prefers shallow seagrass areas with low salinity (Young 1978).

As part of a study on the ecology of undisturbed estuaries, the distribution and abundance of juvenile penaeid prawns in sparse and dense seagrass beds of Tin Can Bay, a subtropical estuary in the Great Sandy Straits region of south-eastern Queensland (Fig. 1), were investigated. The Great Sandy Straits region has extensive areas of intertidal and subtidal seagrass covering about 12300 ha (Lennon and Luck 1990) and supports a $P$. plebejus fishery that produces about $100 \mathrm{t}$ year $^{-1}$ (Trainor 1990). This region is under increasing pressure from coastal resorts, residential development and recreational activities. Ten months into the sampling programme, the above-ground vegetation at the sparse site began to die back, leaving the substratum almost completely bare from November 1992. The term die-back is used to describe the loss of above-ground vegetation, as living rhizomes were always present at the sparse site. This paper describes the physical changes that occurred in the littoral environment and the effect of these on the abundance of juvenile $P$. plebejus and $M$. bennettae. The concept that seagrass loss causes an immediate and lasting decrease in the potential fisheries productivity of an area is questioned. 


\section{Materials and Methods}

Sites

Areas at the southem end of the Great Sandy Strait were identified as potential sampling sites from maps of seagrass distribution derived from satellite imagery (Lennon and Luck 1990). Potential sites were then inspected and the seagrass density assessed. Two sites, sparse and dense (Fig. 1), were selected to represent two contrasting densities of seagrass cover. The sites were $<3 \mathrm{~km}$ apart, exposed to similar weather conditions, $>150 \mathrm{~m}$ from the nearest mangrove stands, and inundated to the same extent at high tide and exposed during the last $2 \mathrm{~h}$ of the ebb tide.

\section{Experimental Design}

Seagrass. For each of the 13 sampling periods, six seagrass samples were randomly collected in a $25 \times 25 \mathrm{~cm}$ quadrat at each site (sparse and dense) the day after beam trawling. A trowel was pushed down around the edges of the sample to cut any rhizomes and roots. Each sample was then lifted into a 10-mm sieve and washed thoroughly. The retained seagrass was identified and above-ground and below-ground portions of each species were separated. Dry weight was determined after drying each sample in an oven for $48 \mathrm{~h}$ at $60^{\circ} \mathrm{C}$.

Water quality. Throughout the study, a submersible data-logger (DataSonde 3) was placed on a navigation marker about $300 \mathrm{~m}$ from the dense site (Fig. 1), recording water temperature, salinity and tidal height each hour.

Prawns. Five samples of benthic post-larval and juvenile prawns at each site were taken at each time with a roller-beam trawl, with each tow lasting $2 \mathrm{~min}$ and covering about $50 \mathrm{~m}$. Samples were collected at night, on

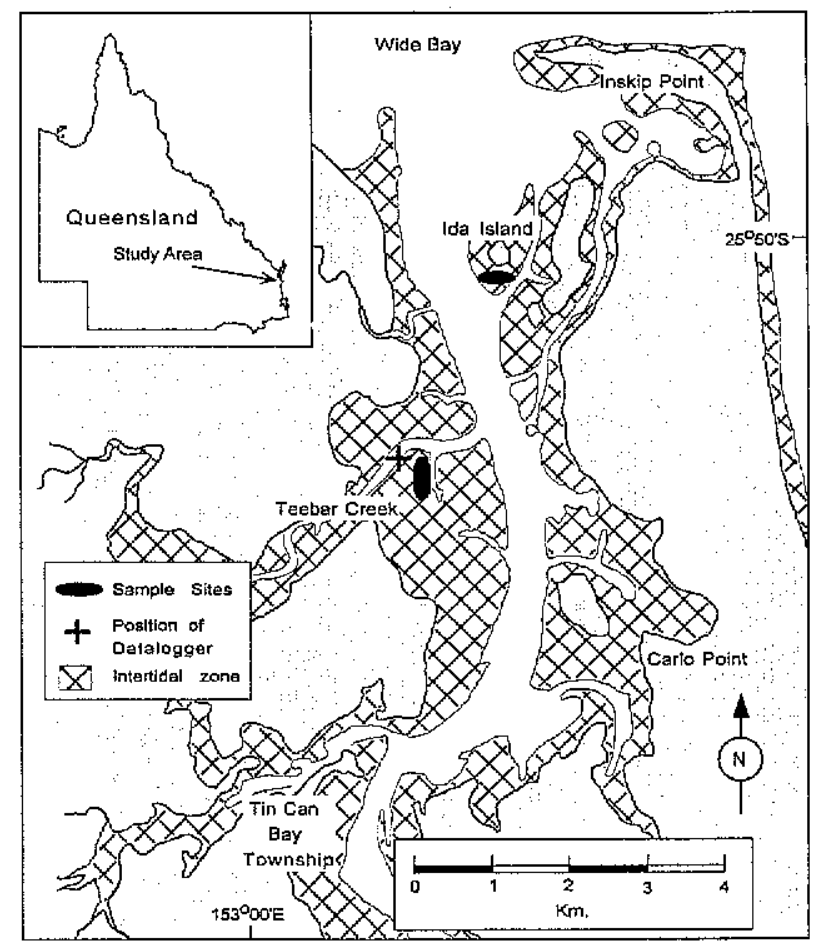

Fig. 1. Sites where samples of Penaeus plebejus, Metapenaeus bennettae and seagrass were taken. Dense seagrass occurred at the Teebar Creek site, sparse seagrass at the Ida Island site. the full moon every second lunar month from November 1991 until September 1993. Samples were taken at the top of the tide to minimize the effect of tidal currents and water depth on catches (Coles 1979). The rollerbeam trawl used is described by Young (1975). Samples were frozen immediately after collection for subsequent identification (Dall 1957; Young 1977), measurement and counting. Only data for benthic post-larval prawns (2-3 mm carapace length, CL) and juyenile prawns (4-11 mm CL) (Vance and Staples 1992) were used in the analysis. Prawns of both size ranges are referred to as juveniles for the rest of this paper. Subadult prawns (>11 mm CL) were excluded from the results as these migrate into deeper water and exhibit greater net avoidance (Young 1975; Coles and Greenwood 1983).

Prawn counts were skewed, so a $\log$ transformation- $\ln (n+1)$-was used to make the variance independent of the mean for parametric testing. The data were divided into three factors - sites, month and year (before and after seagrass die-back)-and into blocks for analysis of variance (ANOVA). Replicate trawls within each site during each sampling period were considered as a block.

\section{Results}

\section{Seagrass}

The predominant seagrass at both sites was Zostera capricomi, with Halophila spp. comprising $<1 \%$ of the total above-ground dry weight. Until August 1992, the mean above-ground seagrass density at the sparse site was $5.5 \pm$ $0.3 \mathrm{~g} \mathrm{~m}^{-2}$ (mean \pm s.e. $)$. Seagrass at this site began to die back during September 1992. During November 1992 remnants of above-ground vegetation remained, but by January 1993 little above-ground vegetation existed (Fig. 2). The mean aboveground dry weight for the period from November 1992 to November 1993 was $0.6 \pm 0.2 \mathrm{~g} \mathrm{~m}^{-2}$. Seagrass cover of the dense site showed seasonal variations, with a mean aboveground dry weight of $42.5 \pm 2.7 \mathrm{~g} \mathrm{~m}^{-2}$ (Fig. 2).

\section{Water Quality}

Between-site differences in salinity and water temperature were considered to be negligible because of the close proximity of the sites. Average salinity was $33.7 \pm$ 0.01 . The high average salinity indicates that the estuary has a strong oceanic influence and is not greatly affected by freshwater inputs. Water temperature averaged $23.4^{\circ} \mathrm{C}$, with a range from $14 \cdot 6^{\circ} \mathrm{C}$ in July 1992 to $32.2^{\circ} \mathrm{C}$ in January 1993. The high maximum temperature resulted from shallow water being heated while it was in the intertidal zone and receding with the falling tide in mid afternoon.

\section{Prawns}

In total, of 35700 individuals of four species of juvenile commercial prawns were caught from the two sites. Penaeus plebejus represented $84.5 \%$ (30158) of the total catch, Metapenaeus bennettae $11.4 \%$ (4084), $M$. endeavouri $2.4 \%$ (869), and $P$. esculentus $1.6 \%$ (589).

$P$. plebejus. Juvenile $P$. plebejus dominated the catches at both sites. Of the total $P$. plebejus catch, $70.4 \%$ (21232) were caught at the sparse site and $29.6 \%(8926)$ at the dense 


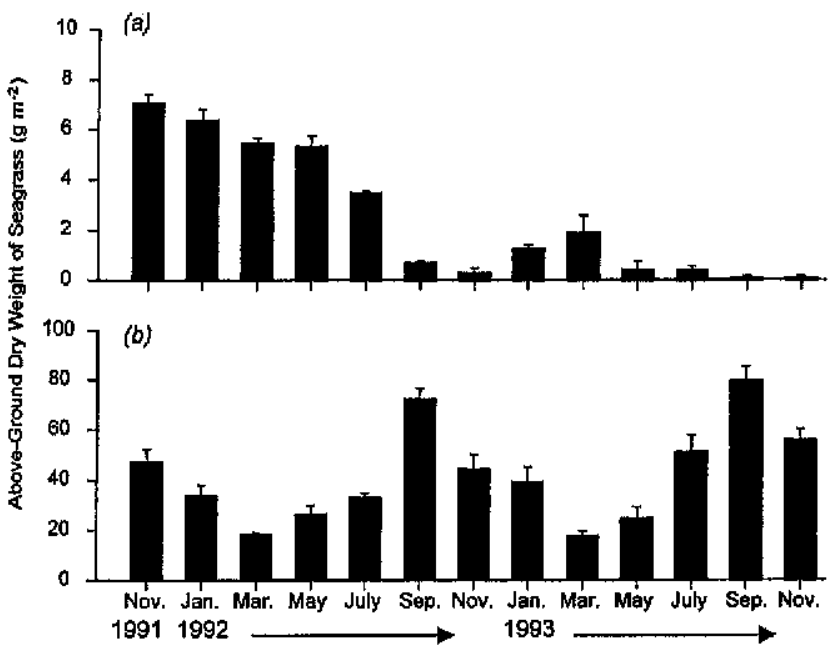

Fig. 2. Above-ground dry weight of seagrass from the (a) sparse site and (b) dense site. Note the different scales for each site. Vertical bars represent the standard error.

site. Site, seasonal and yearly variations in abundance of juveniles caught (Fig. $3 a$ ) resulted in a significant three-way interaction (sites $\times$ month $\times$ year, $P<0.01$ ) (Table 1). This was broken down into a number of smaller interactions. In the first year, before seagrass die-back, abundance of $P$. plebejus was similar at both sites and had common seasonal variations (Fig. 3a). During the second year (after seagrass die-back), significantly more $P$. plebejus juveniles $(P<0.01)$ were caught at the sparse site than at the dense site (Table 1).

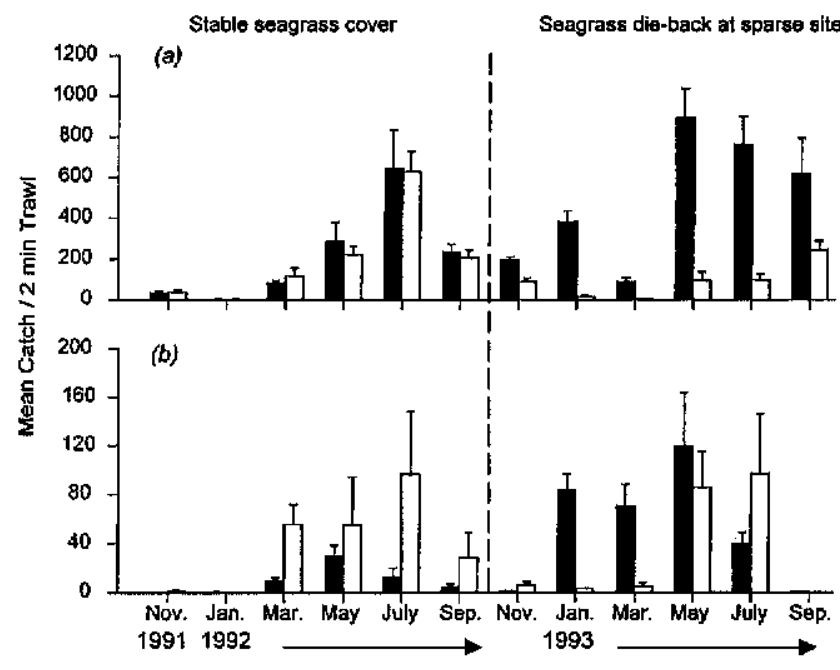

Fig. 3. Bimonthly variations in mean catch per trawl of juvenile (a) Penaeus plebejus and (b) Metapenatus bennettae at the sparse (solid histograms) and dense (open histograms) seagrass sites. Note the different scales for each species. Vertical bars represent standard error. The right side of the dashed line indicates die-back of seagrass at the sparse site.
At both sites, during each year, seasonal variation in the abundance of $P$. plebejus was evident, with catches being highest during winter (May-July) (Fig. 3a). At the sparse site, monthly (seasonal) and yearly differences in abundances occurred, resulting in a significant two-way interaction $(P<0.01)$ (Table 1). Higher abundances were recorded during the second year (after seagrass die-back) compared with those of the previous year. At the dense site, monthly (seasonal) and yearly differences in abundance represented a significant two-way interaction $(P<0.01)$ (Table1). Lower abundances were recorded during the second year (after seagrass die-back).

$M$. bennettae. Juvenile $M$. bennettae occurred at both sites in almost equal numbers, $45.9 \%$ (1873) at the sparse site and $54.1 \%(2211)$ at the dense site. Site, monthly (seasonal) and yearly changes in abundance (Fig. 3b) resulted in a significant three-way interaction $(P<0.05)$ (Table 1). Again this was broken into components. During the first year, significant differences in the abundance at both sites $(P<0.05)$ and seasonally $(P<0.01)$ were seen. During the second year, differences in abundance for both site and month resulted in a significant two-way interaction $(P<0.01)$ (Table 1 ).

Abundance of this species was consistently seasonal, with peaks in winter (May-July) followed by a period of low recruitment in spring (September-November). At the sparse site, increases in the abundance of $M$. bennettae during the second year (Fig. $3 b$ ) and seasonal variation resulted in a two-way interaction $(P<0.01)$. At the dense site, decreases in abundance during the second year and seasonality resulted in a significant two-way interaction $(P<0.01)$. M. bennettae was not expected to be abundant at either site because of its preference (Young 1978) for less saline habitats than those recorded from Tin Can Bay.

\section{Discussion}

The natural loss of the intertidal vegetation may not be as catastrophic to fisheries productivity as it is often considered to be. Significant increases in abundance of juvenile Penaeus plebejus, following the loss of seagrass at the sparse site, suggests that natural seagrass loss may produce alternative habitats suitable as nurseries for $P$. plebejus, thus increasing the potential commercial prawn production of the area.

The ability of other Penaeus spp. to colonize areas in which seagrass or algae has recently been removed is documented from the Gulf of Carpentaria, and from southwestern Western Australia. In the Gulf of Carpentaria, seagrass cover has been linked with the abundance of juvenile Penaeus esculentus and P. semisulcatus (Staples et al. 1985; Poiner et al. 1993; Loneragan et al. 1994). Cyclones during the 1980s damaged large areas of seagrass, 
Table 1. Significant sources of variation for ANOVA of beam trawl catches of juvenile Penaeus plebejus and Metapenaeus bennettae $[\ln (n+1)]$ Only the significant interactions of the highest order are shown. *P<0.05,**P<0.01

\begin{tabular}{|c|c|c|c|c|c|}
\hline Species & Data set & Source of variation & d.f. & s.s. & $F$-ratio \\
\hline \multirow[t]{7}{*}{ P. plebejus } & All data & $\begin{array}{l}\text { Site } \times \text { month } \times \text { year } \\
\text { Residual }\end{array}$ & 5 & $\begin{array}{r}8.49 \\
38.97\end{array}$ & \multirow[t]{2}{*}{$4-18^{*} * *$} \\
\hline & \multirow[t]{2}{*}{ Sparse site only } & Month $\times$ year & 5 & $36 \cdot 63$ & \\
\hline & & Residual & 48 & 13.81 & $25 \cdot 47^{* *: k}$ \\
\hline & Dense site only & $\begin{array}{l}\text { Month } \times \text { year } \\
\text { Residual }\end{array}$ & $\begin{array}{r}5 \\
48\end{array}$ & $\begin{array}{l}50 \cdot 39 \\
25 \cdot 16\end{array}$ & 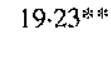 \\
\hline & \multirow[t]{2}{*}{ 1st year only } & Month & 5 & 176.29 & \multirow[t]{2}{*}{$80 \cdot 28^{* * *}$} \\
\hline & & Residual & 48 & 20.57 & \\
\hline & 2nd year only & $\begin{array}{l}\text { Site } \times \text { month } \\
\text { Residual }\end{array}$ & $\begin{array}{r}5 \\
48\end{array}$ & $\begin{array}{l}17 \cdot 27 \\
18 \cdot 40\end{array}$ & 9.01 先* \\
\hline \multirow[t]{5}{*}{ M. bennettae } & A.ll data & $\begin{array}{l}\text { Site } \times \text { month } \times \text { year } \\
\text { Residual }\end{array}$ & $\begin{array}{r}5 \\
95\end{array}$ & $\begin{array}{r}17.01 \\
101.69\end{array}$ & $3 \cdot 21 *$ \\
\hline & Sparse site only & $\begin{array}{l}\text { Month } \times \text { year } \\
\text { Residual }\end{array}$ & $\begin{array}{r}5 \\
48\end{array}$ & $\begin{array}{l}27 \cdot 17 \\
37 \cdot 86\end{array}$ & $6 \cdot 89^{* *}$ \\
\hline & Dense site only & $\begin{array}{l}\text { Month } \times \text { year } \\
\text { Residual }\end{array}$ & $\begin{array}{r}5 \\
48\end{array}$ & $\begin{array}{l}50 \cdot 39 \\
25 \cdot 16\end{array}$ & $19.23 * *$ \\
\hline & Ist year only & $\begin{array}{l}\text { Site } \\
\text { Month } \\
\text { Residual }\end{array}$ & $\begin{array}{r}1 \\
5 \\
48\end{array}$ & $\begin{array}{r}8 \cdot 80 \\
80 \cdot 04 \\
67 \cdot 63\end{array}$ & $11.36^{* * *}$ \\
\hline & 2nd year only & $\begin{array}{l}\text { Site } \times \text { month } \\
\text { Residual }\end{array}$ & $\begin{array}{r}5 \\
48\end{array}$ & $\begin{array}{l}34.74 \\
34.06\end{array}$ & $9 \cdot 79^{* * *}$ \\
\hline
\end{tabular}

causing a species shift in the juvenile prawn fauna from the commercially important $P$. esculentus, $P$. semisulcatus and Metapenaeus endeavouri to the commercially 'unimportant' Metapenaeus spp. and $P$. latisulcatus (Thorogood et al. 1990). $P$. latisulcatus prefers a sandy substratum as nursery areas. The commercial catches of P. latisulcatus in the PeelHarvey estuary of south-western Western Australia have been inversely correlated with the extent of cover of the macroalga Cladophora montagneama (Potter et al. 1991). $P$. plebejus is endemic to the eastern coast of Australia (Montgomery 1990) and inhabits both bare and seagrass habitats (Young and Carpenter 1977; Coles and Greenwood 1983). However, when both substratums occur in the same vicinity, juvenile $P$. plebejus prefers seagrass habitats (Young 1975). Within the available habitat in Tin Can Bay, there was an increase in the abundance of juvenile $P$. plebejus associated with the loss of extensive areas of seagrass. The ability of $P$. plebejus to use unvegetated areas as nursery sites was expected; however, the natural die-back of seagrass in this area may provide greater opportunity for survival than do the vegetated areas.

There is little information on the ability of juvenile prawns to actively select preferred nursery areas after initial settlement into an estuary. Bell and Westoby (1986) made three assumptions about decapod larval settlement into seagrass beds: larvae are distributed patchily when they are ready to settle; larvae do not discriminate between beds of different physical complexity; and individuals redistribute themselves within a bed to select microsites favouring survival. These assumptions should be applicable to the abundances of $P$. plebejus and $M$. bennettae at the two seagrass sites.

The number of juvenile $P$. plebejus recruits that settled and remained in the two sites was similar before the seagrass die-back (i.e. in 1992). This would be expected as larvae should settle patchily onto the two different seagrass densities that offered similar nursery conditions, i.e. a physically complex habitat. The loss of the seagrass at the sparse site removed the physical complexity of the substratum and should have caused a decrease in the abundance of prawns on that substratum. This was not the case, suggesting that the juvenile prawns actively selected the sparse site as a preferred nursery ground. Decreases in the overall abundance at the dense site, from the first to the second year, could be due to the patchiness of larvae entering the estuary or the active settling of larvae onto areas that provided better opportunities of survival.

Salinity is a major influence in determining the suitability of a nursery area (Ruello 1973; Young 1978; Coles 1979) for penaeid prawns as they can detect changes of 1 unit of salinity (Hughes 1969). Juveniles of $P$. plebejus prefer saline areas (Young 1978) and were similarly abundant at both 
seagrass sites when vegetated. This would have allowed movements after settlement to be restricted to micosites within the bed. As both sites were in close proximity and the salinity averaged $>30$, it is unlikely that salinity influenced preferential settlement to one or other of the sites. Even though juveniles of $M$. bennettae prefer low salinity $(<20)$ and seagrass (Young 1978; Coles and Greenwood 1983), they were continuously caught at both sites. The preference for lower salinities suggests that the $M$. bennettae juveniles had not settled into their preferred nursery environment and should attempt to move to a more suitable habitat. No significant decrease in abundance of $M$. bennettae juveniles occurred even after the seagrass die-back at the sparse site, indicating an inability to move between habitats after their initial settlement. Other environmental factors such as water temperature, turbidity and sediment composition have been previously investigated, with no single parameter being a consistent nursery area requirement for Penaeus spp. or Metapenaeus spp. (Penn 1981).

The catchability of juvenile prawns changes with size, current and substratum type (Young 1975; Coles and Greenwood 1983). The loss of seagrass was not considered to influence the catchability of juvenile prawns. The aboveground vegetation present before the die-back occurred was relatively short $(<40 \mathrm{~mm}$ leaf length) and would have provided little protection from capture.

The Great Sandy Straits region currently has extensive dynamic areas of sand, mud and seagrass flats, with seagrass beds continually extending and dying back. The die-back of seagrass may provide conditions favourable to the survival of juvenile $P$. plebejus on the intertidal areas through a combination of high salinity and bare substratum. As environmental conditions change, the suitability of the habitat for $P$. plebejus survival will also change, providing (in part) an explanation for year-to-year variations in commercial prawn catches of the region.

\section{Acknowledgments}

I thank Mr W. Young, Mr S. McKinnon, Mr M. Johnson and $\mathrm{Mr} \mathrm{D}$. Smallwood for their assistance in the collection of field samples and Dr R. Brown, Ms J. Robins, Ms N. Chinivasagam, Ms A. Arends and Mr Z. Sarac for critical and constructive comment on this manuscript. Dr D. Die provided assistance with the statistical analyses. This project was funded by the Fisheries Research and Development Corporation.

\section{References}

Bell, J. D., and Westoby, M. (1986). Variation in seagrass height and density over a wide spatial scale: effects on fish and decapods. Journal of Experimental Marine Biology and Ecology 104, 275-95.

Coles, R. G. (1979). Catch size and behaviour of pre-adults of three species of penaeid prawns as influenced by tidal current direction, trawl alignment, and day and night periods. Journal of Experimental Marine Biology and Ecology 38, 247-60.
Coles, R. G., and Greenwood, J. G. (1983). Seasonal movement and size distribution of three commercially important Australian prawn species (Crustacea:Penaeidae) within an estuarine system. Australian Journal of Marine and Freshwater Research 34, 727-43.

Coles, R. G., and Lee Long, W. J. (1985). Juvenile prawn biology and the distribution of seagrass prawn nursery grounds in the southeastern Gulf of Carpentaria. In 'Second Australian National Prawn Seminar'. (Eds P. C. Rothlisberg, B. J. Hill and D. J. Staples.) pp. 55-60. (NPS2: Cleveland, Australia.)

Coles, R. G., Lee Long, W. J., Watson, R. A., and Derbyshire, K. J. (1993). Distribution of seagrasses, and their fish and penaeid prawn communities, in Cairns Harbour, a tropical estuary, northern Queensland, Australia. Australian Journal of Marine and Freshwater Research 44, 193-210.

Dall, W. (1957). A revision of the Australian species of Penaeinae (Crustacea:Decapoda:Penaeidae), Australian Journal of Marine and Freshwater Research 8, 136-239.

Dall, W., Hill, B. J., Rothlisberg, P. C., and Staples, D. J. (1990). The biology of the Penaeidae. In 'Advances in Marine Biology'. Vol. 27. (Eds J. H. S. Blaxter and A. J. Southward.) pp. 283-314. (Academic Press: London.)

Hughes, D. A. (1969). Response to salinity change as a tidal transport mechanism of pink shrimp, Penaeus dourarum. Biological Bulletin (Woods Hole) 136, 43-53.

Hughes, D. A. (1972). On the endogenous control of tide-associated displacements of pink shrimp, Penaeus dourarum Burkenroad. Biological Bulletin (Woods Hole) 142, 271-80.

Lennon, P., and Luck, P. (1990). Seagrass mapping using Landsat TM data: a case study in southern Queensland. Asian-Pacific Remote Sensing Journal 2, 1-7.

Loneragan, N. R., Kenyon, R. A., Haywood, M. D. E., and Staples, D. J. (1994). Population dynamics of juvenile tiger prawns (Penaeus esculentus and $P$, semisulcatus) in seagrass habitats of the western Gulf of Carpentaria, Australia. Marine Biology (Berlin) 119, 133-43.

Montgomery, S. S. (1990). Movements of juvenile eastern king prawns, Penaeus plebejus, and identification of stock along the east coast of Australia. Fisheries Research (Amsterdam) 9, 189-208.

Penn, J. W. (1981). A review of mark-recapture and recruitment studies on Australian penaeid shrimp. Kuwait Bulletin of Marine Science 2, 227-47.

Poiner, I. R., Conacher, C. A., Staples, D. J., and Moriarty, D. J. W. (1992). Seagrasses-why are they important? In 'Moreton Bay in the Balance'. (Ed. O. N. Crimp.) pp. 41-53. (Australian Littoral Society/ Australian Marine Science Consortium: Brisbane.)

Poiner, I. R., Loneragan, N. R., and Conacher, C. A. (1993), Maintain or modify-alternative views of managing critical fisheries habitat. In 'Sustainable Fisheries through Sustaining Fish Habitat'. Australian Society of Fish Biology Workshop, August 1992. (Ed. D. A. Hancock.) pp. 3-13. (Australian Government Publishing Service: Canberra.)

Potter, I. C., Manning, R. J. G., and Loneragan, N. R. (1991). Size, movements, distribution and gonadal stage of the western king prawn (Penaeus latisulcatus) in temperate estuary and local marine waters. Journal of Zoology (London) 223, 419-45.

Racek, A. A. (1959). Prawn investigations in eastern Australia. NSW State Fisheries Research Bulletin No. 6. 57 pp.

Ruello, N. V. (1973). Burrowing, feeding, and spatial distribution of the school prawn Metapenaeus macleayi (Haswell) in the Hunter River region, Australia. Journal of Experimental Marine Biology and Ecology 13, 189-206.

Staples, D. J. (1984). Habitat requirements of juvenile prawns. In 'The Potential for Aquaculture in Queensland'. (Eds B. R. Pollock and R. H. Quinn.) pp. 87-102. Queensland Department of Primary Industries Conference Workshop Series No. QC83012. 
Staples, D. J., Vance, D. J., and Heales, D. S. (1985). Habitat requirements of juvenile penaeid prawns and their relationship to offshore fisheries. In 'Second Australian National Prawn Seminar'. (Eds P. C. Rothlisberg, B. J. Hill and D. J. Staples.) pp. 47-54. (NPS2: Cleveland, Australia.)

Thorogood, C. A., Poiner, I. R., Somers, I. F., and Staples, D. (1990). Seagrass and cyclones in the western Gulf of Carpentaria, 1989 update. CSIRO Marine Laboratories Information Sheet No. 7.

Trainor, N. (1990). Review of the east coast otter trawl fishery. The Queensland Fisherman 8(9), 25-32.

Vance, D. J., and Staples, D. J. (1992). Catchability and sampling of three species of juvenile penaeid prawns in the Embley River, Gulf of Carpentaria, Australia. Marine Ecology Progress Series 87, 201-13.

Young, P. C. (1975). Preliminary observations on the environment and biology of the juvenile king prawn (Penaeus plebejus) in Moreton Bay, Queensland. In 'Proceedings of the National Publishing Seminar, 1973'. (Ed. P. C. Young.) pp. 18-36. (Australian Government Publishing Service: Canberra.)
Young, P. C. (1977). A working key to the common species of penaeid prawn from Moreton Bay, Queensland, Australia (Penaeidae:Natantia). CSIRO Division of Fisheries Report No. 72.12 pp.

Young, P. C. (1978). Moreton Bay, Queensland: a nursery area for juvenile penaeid prawns. Australian Journal of Marine and Freshwater Research 29, 55-75.

Young, P. C., and Carpenter, S. M. (1977). Recruitment of postlarval penaeid prawns to nursery areas in Moreton Bay, Queensland. Australian Journal of Marine and Freshwater Research 28, 745-73.

Manuscript received 20 April 1994; revised 8 March and 1 September 1995; accepted 1 September 1995 